\title{
BMJ Global Health Food and beverage industry interference in science and policy: efforts to block soda tax implementation in Mexico and prevent international diffusion
}

\author{
Andrea Pedroza-Tobias (D) , ${ }^{1}$ Eric Crosbie (D) , ${ }^{2,3}$ Melissa Mialon (D) , ${ }^{4}$ \\ Angela Carriedo (D) , ${ }^{5}$ Laura A Schmidt (D) ${ }^{6,7}$
}

To cite: Pedroza-Tobias A, Crosbie E, Mialon M, et al. Food and beverage industry interference in science and policy: efforts to block soda tax implementation in Mexico and prevent international diffusion. BMJ Global Health 2021;6:e005662. doi:10.1136/ bmjgh-2021-005662

Handling editor Seye Abimbola

- Additional supplemental material is published online only. To view, please visit the journal online (http://dx.doi.org/10. 1136/bmjgh-2021-005662).

Received 9 March 2021 Accepted 14 July 2021

Check for updates

C Author(s) (or their employer(s)) 2021. Re-use permitted under CC BY-NC. No commercial re-use. See rights and permissions. Published by BMJ.

For numbered affiliations see end of article.

Correspondence to Dr Laura A Schmidt; Laura.Schmidt@ucsf.edu

\section{ABSTRACT}

Mexico is the largest soft drink market in the world, with high rates of obesity and type 2 diabetes. Due to strains on the nation's productivity and healthcare spending, Mexican lawmakers implemented one of the world's first public health taxes on sugar-sweetened beverages (SSBs) in 2014. Because Mexico's tax was designed to reduce SSB consumption, it faced strong opposition from transnational food and beverage corporations. We analysed previously secret internal industry documents from major corporations in the University of California San Francisco's Food Industry Documents Archive that shed light on the industry response to the Mexican soda tax. We also reviewed all available studies of the Mexican soda tax's effectiveness, contrasting the results of industryfunded and non-industry-funded studies. We found that food and beverage industry trade organisations and front groups paid scientists to produce research suggesting that the tax failed to achieve health benefits while harming the economy. These results were disseminated before non-industry-funded studies could be finalized in peer review. Mexico still provided a real-world context for the first independent peer-reviewed studies documenting the effectiveness of soda taxation-studies that were ultimately promoted by the global health community. We conclude that the case of the Mexican soda tax shows that industry resistance can persist well after new policies have become law as vested interests seek to roll back legislation, and to stall or prevent policy diffusion. It also underscores the decisive role that conflict-of-interest-free, peer-reviewed research can play in implementing health policy innovations.

\section{INTRODUCTION}

Mexico is the largest soft drink market in the world, with average consumption at 151 L per capita per year. ${ }^{1}$ The country also has disproportionately high rates of obesity and type 2 diabetes. ${ }^{2}$ Due to strains on the nation's productivity and healthcare spending, Mexican lawmakers implemented one of the world's first public health taxes on sugar-sweetened beverages (SSBs) on 1

\section{Summary box}

Food and beverage industry opposition can intensify after a soda tax has been enacted because vested interests hope to weaken or delay implementation, and prevent policy diffusion to other countries.

- After the Mexican soda tax took effect in 2014 transnational food and beverage corporations recruited scientists to produce credible-seeming evidence that the policy was failing to achieve its goal of reducing sugar-sweetened beverage (SSB) consumption.

- Industry-funded studies were rapidly disseminated and amplified outside the scientific literature in international news outlets and global health policy discussions to argue that the tax was failing to achieve its goal of reducing SSB consumption.

- Mexico ultimately played a decisive role in garnering international attention on soda taxes by providing the first real-world context for peer-reviewed studies documenting their effectiveness.

January 2014 as part of its federal budget. ${ }^{3}$ At the time, a few developed countries with low consumption rates had soda taxes (eg, France, Finland), ${ }^{4}$ but there was no empirical research on their effectiveness, only price-elasticity simulations based on alcohol and tobacco taxation. These simulations suggested that a $10 \%$ increase in the price of SSBs was associated with an $11 \%$ decrease in consumption. ${ }^{56}$

Since Mexico implemented its tax, soda taxation has become an international movement. ${ }^{7}$ Thirty-five countries around the globe have adopted SSB taxation policies, including Chile, India, and the UK. ${ }^{48}$ Three systematic reviews now conclude that taxation is effective for reducing SSB consumption, ${ }^{9-11}$ with the first empirical studies based on Mexico. ${ }^{12-17}$ 
Because they are designed to reduce SSB consumption, soda tax proposals and related public health strategies (eg, warning labels and SSB sales bans in schools) have routinely faced opposition by transnational food and beverage corporations in Mexico and globally. ${ }^{18} 19$ A key opposition strategy is to fund scientists to produce evidence favourable to industry interests. ${ }^{18}{ }^{20}$ While industry opposition during debates over passage of the Mexican soda tax has already been documented, ${ }^{19}$ 21-24 little is known about the industry's tactics after the policy took effect.

We reviewed and organised in chronological order previously secret internal industry documents contained in the University of California San Francisco's Food Industry Documents Archive ${ }^{25}$ to investigate the industry's reponse to implementation of Mexico's tax both within Mexico and in international context (online supplemental table 1). This publicly available repository contains internal memos, emails and other private communications between executives from leading transnational beverage corporations, such as Coca-Cola, and the researchers they fund. These documents, many obtained through litigation and under freedom-of-information laws, provide a window into the behind-the-scenes motives, interests and strategies of transnational food and beverage corporations that resist regulations, such as soda taxes, designed to reduce consumption of ultra-processed foods and beverages at the population level. We also used standard qualitative analysis methods, guided by the policy dystopia model,${ }^{26}{ }^{27}$ to review all available research reports on evaluations of the effectiveness of Mexico's tax policy. Here, we compared the results reported by industry-funded and non-industry-funded studies to better understand the role of science in this debate. (See online supplemental data for details on document sources and research methods.)

\section{THE FOOD AND BEVERAGE INDUSTRY'S RESPONSE TO MEXICO'S IMPLEMENTATION OF A SODA TAX}

During 2014, Mexico's Health Minister, Mercedes Juan, who formerly directed a Nestlé-funded research organisation, created the Mexican Observatory on Non-communicable Diseases (OMENT) to monitor obesity and diabetes, including the effects of the soda tax. ${ }^{28}$ Juan appointed an Advisory Council with representatives tied to the food and beverage industry, ${ }^{21} 29$ including key trade groups that had opposed passage of the tax, arguing that it would harm the economy.

In June 2015, Mexican government scientists reported that nationwide, SSB purchases appeared to have gone down by $6 \%$ because of the tax. ${ }^{30}$ In July, the National Alliance of Small Merchants (ANPEC) gave a press conference to present data suggesting that 30000 small stores had been forced to close down due to the tax. ${ }^{31}$ Shortly thereafter, the National Association of Soda and Carbonated Water Producers (ANPRAC) released a study claiming that the tax was regressive because it negatively impacted Mexicans with low purchasing capacity. ${ }^{32}$ Soon came another industry-funded study reporting that SSB sales had decreased by 3\%-4.4\%, amounting to a negligible reduction in daily calories for the average Mexican, while producing 10815 job losses. ${ }^{33}$ Industry-funded researchers at the Mexican Autonomous Institute of Technology (ITAM) released yet another study concluding that, while SSB purchases had decreased by $6.5 \%$, total calories were reduced by only $1 \%$, with no impact on obesity. ${ }^{34}$ (See online supplemental table 2 for details on all studies.)

In late 2015, Coca-Cola and its Mexican bottlers began lobbying for reductions in the tax on lower-sugar beverages to create 'an incentive based on the reduction of the caloric content to effectively impact the fight against obesity'. ${ }^{35}$ The idea appeared in recommendations by the Finance Commission of the Chamber of Deputies for the 2016 federal budget. ${ }^{36} 37$

In September 2015, 1 month prior to the federal budget vote, the Mexican Branch of the International Life Sciences Institute (ILSI Mexico), a Coca-Colafunded scientific front group at the time,${ }^{38}$ sponsored the national symposium, Sweeteners and Health. Cosponsoring was the Rippe Lifestyle Institute of Shrewsbury, Massachusetts, USA, a centre providing research services to beverage corporations, including Coca-Cola and PepsiCo. ${ }^{39}$ In a series of private emails, its founder, Dr James Rippe, networked with other US academics to recruit scientists to present research at the symposium, promising 'a modest honorarium if you decide to turn your presentation into one of the ASN (American Society for Nutrition) journals or another academic journal'. ${ }^{40}$ Rippe noted that 'the symposium comes at a very important time in Mexico and relates to a number of issues that are very important in this country'. ${ }^{40}$ Speakers at the symposium argued that 'sugar is not the enemy, the problem is calories', ${ }^{41}$ and questioned whether Mexico was 'taxing the right food group, if their intention is to curb obesity'. ${ }^{42}$ In the plenary session, Rippe stated that 'taxing SSBs will not reduce consumption, and will not do anything meaningful for obesity and diabetes'. ${ }^{43}$ During the symposium, a report was circulated claiming that even with a much-larger tax of 20\%-40\%, 'the impact on BMI (body mass index) would be marginal'. ${ }^{4}$

The symposium drew negative press for ILSI Mexico, ${ }^{45}$ including criticisms that international scientists had been recruited to 'fight the tax'. ${ }^{45}{ }^{46}$ ILSI International ultimately suspended ILSI Mexico 'for engaging in activities that can be construed to be policy advocacy and/or public relations efforts to influence policy'. ${ }^{47}$ In a private email, Alex Malaspina, former Coca-Cola executive and Director of ILSI International, wrote to a Coca-Cola-funded scientist at the University of Colorado, Dr James Hill, about 'the mess ILSI Mexico is in because they sponsored in September a sweeteners 
conference when the subject of soft drinks taxation was discussed ... A real mess'. ${ }^{48}$

The proposal to reduce the Mexican soda tax ultimately passed in the Chamber of Deputies ${ }^{49}$ but failed in the Senate, leaving the original tax policy in place. ${ }^{50}$

In January 2016, the first peer-reviewed empirical study evaluating the Mexican soda tax appeared in BMJ. ${ }^{12}$ Industry stakeholders responded in March 2016 with another academic symposium featuring Mexican, American, and Canadian industry-funded scientists presenting findings that soda taxes fail to impact obesity. ${ }^{51}$ Months later, ANPRAC launched the website, calorictaxes.com, to disseminate industry-funded research showing that the tax had failed to impact SSB consumption or obesity, while imposing significant economic hardships on the poor. ${ }^{52}$

\section{THE MEXICAN SODA TAX IN INTERNATIONAL CONTEXT}

Our analysis of internal industry documents revealed that numerous Coca-Cola executives leveraged their global networks to disseminate the above-described industry-funded studies along with their key messages that the Mexican tax failed to lower SSB consumption and was harmful to the economy. ${ }^{53-58}$ In 2015, Coca-Cola International's Manager of Public Affairs emailed some of these studies to executives in Communications and Government Relations as 'relevant and useful updates on the excise tax in Mexico ... (for) engaging stakeholders to demonstrate why excise taxes on our products are not effective policy mechanisms and can have unintended negative consequences, such as significant job losses'. ${ }^{59}$ Coca-Cola's Vice President of Government Relations and Public Affairs further disseminated the studies to company executives on the Global Pacific leadership team, noting that, 'After the call today, please find all of the latest materials to us in responding to the claims that the excise tax in Mexico has been effective'. ${ }^{59}$

In January 2016, the WHO Commission on Ending Childhood Obesity issued recommendations that nation states consider soda taxes for the prevention of obesity and non-communicable diseases (NCDs) ${ }^{60}$ A February-March 2016 'classified-internal use only' document underscored the degree to which CocaCola executives internally viewed soda taxes to be a significant threat to the company's global enterprises. Figure 1 is reprinted from an international strategy document found in the Food Industry Documents Library, called the 'radar screen', which was produced by senior managers in Government Relations for CocaCola Europe. This radar screen was a 'public policy risk matrix'. It compared 49 governmental policy threats to Coca-Cola's business interests in the European Union (on the $\mathrm{Y}$ axis) against the likelihood that each could

\section{Public policy risk matrix \& lobby focus}

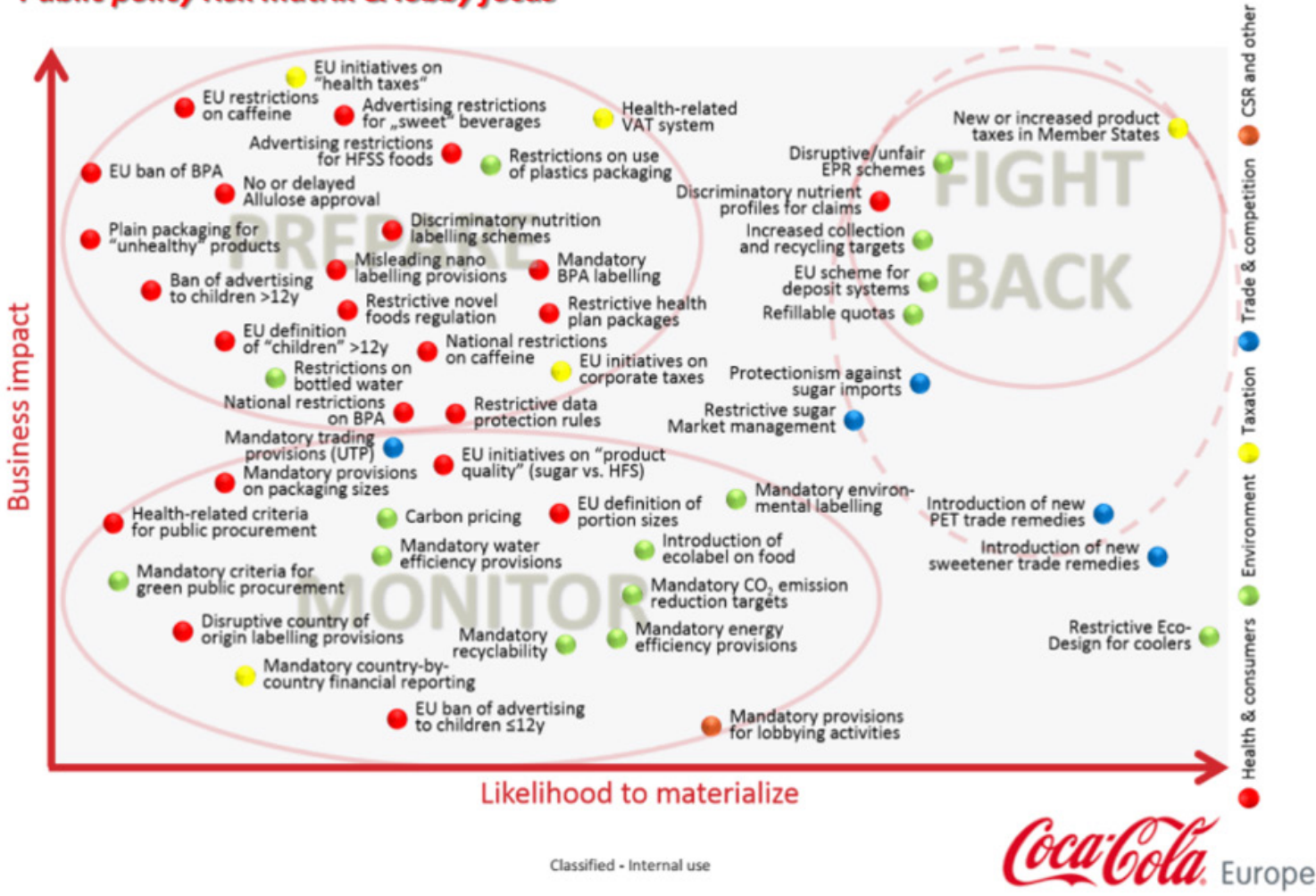

Figure 1 Coca-Cola Europe: radar screen for monitoring public policy threats. Source: University of California San Francisco's Food Industry Documents Archive. ${ }^{58}$ BPA, Bisphenol A; EU, European Union; HFS, high-fructose syrup; HFSS, high fat, sugar and salt; PET, Polyethylene Terephthala; UTP, Unilsted Trading Privileges; VAT, value added tax. 
materialise in member countries (on the $\mathrm{X}$ axis). Notably, of all 49 public policy threats, new tax policies were assessed to have the greatest 'business impact' on Coca-Cola and were also assessed to have a strong 'likelihood to materialise'. ${ }^{58}$

When a New York Times reporter expressed interest in 'exploring the premise that there has been a rise in the number of city and state beverage tax proposals... (and) that this rise can be linked to the 'success' of the tax in Mexico', the Vice President of Policy from the American Beverage Association (ABA) shared data from an industryfunded Mexican study ${ }^{34}$ showing that 'the tax has failed to improve health as its proponents claimed, it is regressive and costs jobs'. ${ }^{61}$ Following an inquiry by the Wall Street Journal about the 2016 BMJ study showing the tax had decreased SSB sales, Coca-Cola's Director of Global Affairs and Communications referred reporters to trade groups that had 'multiple studies from well-respected institutions in Mexico (ITAM, COLMEX, UANL, supported by funding from industry) that make clear the tax was ineffective'. ${ }^{62}$ He also provided a pre-release study funded by the ABA showing that SSB consumption in Mexico had returned to its pretax baseline alongside 3000 job losses—claims that made their way into newsprint. ${ }^{62}$

When in 2017, the third peer-reviewed paper on the Mexican tax appeared in Health Affairs showing a sustained decline in SSB consumption over 2years, ${ }^{13}$ the International Council of Beverages Association (ICBA) stepped in. As the main trade association for the global beverage industry, ICBA released a statement that 'the study does not show any impact from the tax on the obesity rates in Mexico', and called for alternative 'evidence-based solutions' via local partnerships between government and industry. ${ }^{63}$ Citing industry-funded studies, ICBA disseminated a fact sheet to its global partners outlining 'a dozen reasons why soft drink taxes fall flat'. ${ }^{64}$

In 2018, in preparation for the United Nations (UN) high-level meeting on NCDs, global health commissions discussed soda taxation as an evidence-based NCD prevention strategy, citing peer-reviewed research on the Mexican tax. ${ }^{65}$ Internal email communications among Coca-Cola executives called this meeting 'the most important event ahead in the NCD field' and expressed concerns that the Mexican delegation was among 'the most vocal proponents of restricting private sector engagement with the WHO' ${ }^{66}$ In preparation for the high-level meeting, WHO released the report, Time to Deliver, which proposed 'best buys' for the prevention and management of NCDs, including tobacco and alcohol taxation. ${ }^{67}$ In a public comment, ICBA levied methodological criticisms of the Health Affairs paper on the Mexican tax, noting that 'regrettably, the authors of this article are relying on a theoretical model' ${ }^{68}$ WHO's final report, Time to Deliver, stopped short of formally recommending soda taxes due to dissent by the US delegate, ${ }^{69}$ but noted 'broad support from many Commissioners' ${ }^{67}$
CONTRASTING MESSAGES FROM INDUSTRY-FUNDED AND NON-INDUSTRY-FUNDED RESEARCH ON THE MEXICAN SODA TAX

Industry-funded reports, none of which were peer reviewed, became available within the first year of policy implementation. It was not until January 2016 that nonindustry-funded evaluations of the Mexican tax policy began to appear in the peer-reviewed scientific literature. (See online supplemental table 2 for details on all studies.) We identified that the food and beverage industries funded studies that produced discursive strategies aligned to their interests, to play down the effectiveness of the Mexican soda tax (online supplemental table 3).

Industry-funded studies documented negative impacts of the soda tax on the Mexican economy, arguing that the policy will lead to lost jobs, store closures and affect the economy of the country, whereas non-industry-funded evaluations found none. For example, an industryfunded study, using an input-output econometric model, estimated that the tax had led to 10815-42 385 job losses and an economy-wide loss of 6.4 billion pesos (US $\$ 378$ million) during its first year, amounting to a $0.4 \%$ loss of Gross Domestic Product (GDP) ${ }^{33}$ In contrast, a nonindustry-funded study analysed three nationally representative surveys to estimate changes in unemployment rates after adjusting for contextual variables. Authors found no significant employment changes associated with the tax, noting that sales of untaxed beverages had increased to 'offset the potential negative effect on employment'. ${ }^{70}$

Industry-funded studies made arguments related to social justice, such as criticising the tax as regressive, and arguing that the policy was unfair to the poorest: even though tax revenues were collected 'mainly from the richest households, the tax burden (was) heavier in the poorest households'. ${ }^{33}$ Industry-funded studies also argued that the "cost of the policy was particularly harmful in a situation that is notorious for the problems of inequity and poverty'. ${ }^{32}$ Conversely, the first non-industryfunded, peer-reviewed paper on the tax, published in 2016 by BMJ, ${ }^{12}$ found disproportionately large reductions in SSB purchases by lower-income households and concluded that this, plus health and productivity gains in these households, could potentially amount to a progressive, not regressive, tax effect.

Regarding public health benefits, two industry-funded studies $^{33} 34$ and three non-industry-funded studies ${ }^{12} 1371$ evaluated changes in SSB sales following implementation of the soda tax. Although all reported statistically significant reductions in SSB sales, which ranged from 3.4\% to $7.3 \%$, the interpretation of results differed depending on who funded the research. Industry-funded studies interpreted these declines as neglible, when calculated in terms of the calories they represented in an average Mexican's diet, suggesting that it was meaningless from a health standpoint. Two industry-funded studies emphasised that no changes had been observed in rates of obesity during the first 2 years of the tax. ${ }^{33}{ }^{34}$ Studies conducted by scientists without industry ties, in contrast, 
assumed that with such a small tax and only 2 years of implementation, empirical studies could not realistically be expected to find changes in obesity rates. ${ }^{72}$ However, three peer-reviewed non-industry-funded studies published modelling results that used observed declines in SSBs consumption to project the prevalence of obesity over a 10-year period, finding significant reductions. ${ }^{73-75}$

\section{CONCLUSION}

It is well documented that health-harming industries fund scientists to produce research to undermine new health regulations that, if enacted, could threaten commercial interests. ${ }^{22-24} 7677$ The case of the Mexican soda tax shows that industry resistance can persist after new policies have become law as vested interests seek to roll back legislation, and to stall or prevent policy diffusion on an international basis. Immediately upon implementation, the same food and beverage industry stakeholders that had opposed passage of the Mexican tax took oversight positions on government advisory panels monitoring its effects and lobbied lawmakers to reduce the tax rate. Internal industry documents have shown that food and beverage executives feared the international diffusion of soda taxation and attempted to forestall its global diffusion by amplifying industry-funded research claims. They sought to combat emerging evidence that Mexico's tax was effective. Ultimately, since Mexico implemented its tax, 35 countries have adopted similar measures. ${ }^{48}$

When health policy innovations are so new that they lack empirical research, industry-funded studies can be mobilised quickly to define an industry-friendly narrative. ${ }^{78-80}$ It took 2 years for independent evaluations of the Mexican tax to begin appearing in peer-reviewed scientific journals. In the breech, industry stakeholders within Mexico, supported by a global infrastructure of trade organisations and scientific front groups, were able to quickly generate credible-seeming evidence that the policy was a failure. Industry-sponsored studies, none of which were peer-reviewed, were rapidly published and disseminated at scientific meetings to establish a narrative that this policy was disproportionately affecting lowincome households, producing job losses and lowering Mexico's GDP, all while failing to lower SSB consumption or tackle obesity. This narrative drew on the image of neutral, unbiased science for legitimacy. Thus, when the Mexico-based scientific front group for the industry, ILSI Mexico, became too blatant in its efforts to undermine the tax, it was quickly censured and closed down.

Our literature review found that industry-funded studies routinely used discursive strategies to play down the effectiveness of the soda tax policy in Mexico. They issued economic (eg, loss of jobs), social justice (eg, tax is regressive) and public health arguments (eg, tax did not reduce obesity) similar to those previously used by the tobacco industry. ${ }^{262781}$ Food and beverage industry interference went beyond simply 'spinning' emerging evidence of the tax's effectiveness. Industry-funded research was cited within Mexico to encourage lawmakers to lower the tax-a proposal that passed in the Mexican Chamber of Deputies but failed in the Senate. Media outlets within Mexico were important for exposing industry's recruitment of US-based scientists to advocate against the tax. This highlights the ongoing need to alert scientists, policy-makers and media outlets about conflicts of interest and why commercial interests can bias research.

Over time, industry-funded studies on Mexico were disseminated globally by beverage industry executives seeking to contain soda taxation within Mexico. As the threat of international diffusion grew, executives in transnational beverage corporations, such as Coca-Cola, aided by their global trade associations, amplified the narrative of a failed Mexican tax across their global communication networks. Industry-funded studies on Mexico were discussed in the international press during the run-up to the 2018 UN high-level meeting on NCDs, but by then, independent, peer-reviewed studies had provided competing evidence, resulting in a moderate degree of support for taxation.

Findings from this study underscore the decisive role that peer-reviewed research can play in implementing progressive public health policies. Mexico created a realworld context for the first peer-reviewed empirical studies demonstrating the effectiveness of taxing SSBs. Despite a notable degree of industry opposition, peer-reviewed evaluations of the Mexican tax eventually garnered the attention of international expert panels on NCDs. ${ }^{60} 6582$ This gave impetus to measured endorsements of soda taxes by the UN and WHO, setting the stage for their growing adoption by countries around the globe.

\section{Author affiliations}

${ }^{1}$ Institute for Global Health Sciences, University of California San Francisco, San Francisco, California, USA

${ }^{2}$ School of Community Health Sciences, University of Nevada, Reno, Nevada, USA ${ }^{3}$ Ozmen Institute for Global Studies, University of Nevada, Reno, Nevada, USA

${ }^{4}$ Trinity Business School, Trinity College Dublin, Dublin, Ireland

${ }^{5}$ World Public Health Nutrition Association, London, UK

${ }^{6}$ Philip R. Lee Institute for Health Policy Studies, University of California San Francisco, San Francisco, California, USA

${ }^{7}$ Department of Humanities and Social Sciences, University of California San Francisco, San Francisco, California, USA

Twitter Andrea Pedroza-Tobias @apedroz9, Melissa Mialon @MIALONMelissa and Angela Carriedo @acarriedo

Acknowledgements The authors are grateful to Kate Tasker and Rachel Takata of the University of California San Francisco's Industry Documents Library for archival support and assistance, and to Dr Cristin Kearns for substantive input on this research.

Contributors All authors contributed to data collection, analysis, interpretation and revision for important intellectual content. LS, EC and AP-T drafted the manuscript.

Funding The work was supported by Bloomberg Philanthropies. AP-T has a scholarship from the Mexican National Council of Science and Technology (CONACyT377279). The funders had no role in design, conduct, collection, management, analysis and interpretation of the data or in the preparation, review or approval of the manuscript.

Competing interests None declared.

Patient consent for publication Not required.

Provenance and peer review Not commissioned; externally peer reviewed. 
Data availability statement Data are available in a public, open access repository.

Supplemental material This content has been supplied by the author(s). It has not been vetted by BMJ Publishing Group Limited (BMJ) and may not have been peer-reviewed. Any opinions or recommendations discussed are solely those of the author(s) and are not endorsed by BMJ. BMJ disclaims all liability and responsibility arising from any reliance placed on the content. Where the content includes any translated material, BMJ does not warrant the accuracy and reliability of the translations (including but not limited to local regulations, clinical guidelines, terminology, drug names and drug dosages), and is not responsible for any error and/or omissions arising from translation and adaptation or otherwise.

Open access This is an open access article distributed in accordance with the Creative Commons Attribution Non Commercial (CC BY-NC 4.0) license, which permits others to distribute, remix, adapt, build upon this work non-commercially, and license their derivative works on different terms, provided the original work is properly cited, appropriate credit is given, any changes made indicated, and the use is non-commercial. See: http://creativecommons.org/licenses/by-nc/4.0/.

\section{ORCID iDs}

Andrea Pedroza-Tobias http://orcid.org/0000-0002-7158-3667

Eric Crosbie http://orcid.org/0000-0002-6219-298X

Melissa Mialon http://orcid.org/0000-0002-9883-6441

Angela Carriedo http://orcid.org/0000-0002-0193-6199

Laura A Schmidt http://orcid.org/0000-0003-4346-7260

\section{REFERENCES}

1 Conway J. Soft drink per capita consumption in the ten most populated countries worldwide 2019. statista, 2020. Available: https://www.statista.com/statistics/505794/cds-per-capitaconsumption-in-worlds-top-ten-population-countries/

2 World Health Organization. Global health Observatory, 2015. Available: https://www.who.int/data/gho

3 Diario Oficial de la Federacion. Ley de INGRESOS de la FEDERACIÓN para EI EJERCICIO fiscal de 2014. Capítulo I de Los Ingresos Y El Endeudamiento Público, 2014. Available: http://www. diputados.gob.mx/LeyesBiblio/abro/lif 2014.htm

4 World Cancer Research Fund International. Building momentum: lessons on implementing a robust sugar sweetened beverage Tax, 2018. Available: https://www.wcrf.org/buildingmomentum

5 Barquera S, Hernandez-Barrera L, Tolentino ML, et al. Energy intake from beverages is increasing among Mexican adolescents and adults. J Nutr 2008;138:2454-61.

6 Colchero MA, Salgado JC, Unar-Munguía M, et al. Price elasticity of the demand for sugar sweetened beverages and soft drinks in Mexico. Econ Hum Biol 2015;19:129-37.

7 Nestle M, politics S, soda T. And winning. New York: Oxford University Press, 2015.

8 Global Food Research Program. Sugary drink taxes around the world, 2020. Available: http://globalfoodresearchprogram.web.unc edu/files/2020/08/SugaryDrink_tax_maps_2020_August_REV.pdf

9 Teng AM, Jones AC, Mizdrak A, et al. Impact of sugar-sweetened beverage taxes on purchases and dietary intake: systematic review and meta-analysis. Obes Rev 2019;20:1187-204.

10 Redondo M, Hernández-Aguado I, Lumbreras B. The impact of the tax on sweetened beverages: a systematic review. Am J Clin Nutr 2018;108:548-63.

11 Backholer K, Sarink D, Beauchamp A, et al. The impact of a tax on sugar-sweetened beverages according to socio-economic position: a systematic review of the evidence. Public Health Nutr 2016;19:3070-84

12 Colchero MA, Popkin BM, Rivera JA, et al. Beverage purchases from stores in Mexico under the excise tax on sugar sweetened beverages: observational study. BMJ 2016;352:h6704.

13 Colchero MA, Rivera-Dommarco J, Popkin BM, et al. In Mexico, evidence of sustained consumer response two years after implementing a sugar-sweetened beverage Tax. Health Aff 2017;36:564-71.

14 Sánchez-Romero LM, Canto-Osorio F, González-Morales R, et al. Association between tax on sugar sweetened beverages and soft drink consumption in adults in Mexico: open cohort longitudinal analysis of health workers cohort study. BMJ 2020;369:m1311.

15 Colchero MA, Molina M, Guerrero-López CM. After Mexico implemented a Tax, Purchases of sugar-sweetened beverages decreased and water increased: difference by place of residence, household composition, and income level. J Nutr 2017;147:1552-7.
16 SW N, Rivera JA, Popkin BM. Did high sugar-sweetened beverage purchasers respond differently to the excise tax on sugar-sweetened beverages in Mexico? Public Health Nutr 2019;22:750-6.

17 Barrientos-Gutiérrez T, Colchero MA, Sánchez-Romero LM. Posicionamiento sobre Los impuestos a alimentos no básicos densamente energéticos Y bebidas azucaradas. Salud Publica Mex 2018;60:586

18 Fooks GJ, Williams S, Box G. Corporations' use and misuse of evidence to influence health policy: A case study of sugarsweetened beverage taxation. Global Health 2019;15:1-20.

19 Gómez EJ. Coca-Cola's political and policy influence in Mexico: understanding the role of institutions, interests and divided Society. Health Policy Plan 2019;34:520-8.

20 Barnoya J, Nestle M. The food industry and conflicts of interest in nutrition research: a Latin American perspective. J Public Health Policy 2016;37:552-9.

21 Carriedo A, Lock K, Hawkins B. Policy process and Non-State actors' influence on the 2014 Mexican soda Tax. Health Policy Plan 2020;35:941-52.

22 Ojeda E, Torres C, Carriedo Ángela, et al. The influence of the sugarsweetened beverage industry on public policies in Mexico. Int $J$ Public Health 2020;65:1037-44.

23 James E, Lajous M, Reich MR. The politics of taxes for health: an analysis of the passage of the sugar-sweetened beverage Tax in Mexico. Health Syst Reform 2020;6:e1669122.

24 Carriedo Lutzenkirchen A. A policy analysis of the 2014 Mexican soda Tax. London, UK: London School of Hygiene \& Tropical Medicine, 2017.

25 University of California San Francisco. Food industry documents, 2020. Available: https://www.industrydocuments.ucsf.edu/food/

26 Mialon M, Julia C, Hercberg S. The policy dystopia model adapted to the food industry : the example of the Nutri-Score saga in France. World Nutr 2018;9:109-20.

27 Ulucanlar S, Fooks GJ, Gilmore AB. The policy dystopia model: an interpretive analysis of tobacco industry political activity. PLoS Med 2016;20:e1002125. doi:10.1371/journal.pmed.1002125

28 Diario Oficial de la Federacion. Acuerdo por el que se crea el Consejo Asesor del Observatorio Mexicano de Enfermedades No Transmisibles, 2014. Available: http://www.dof.gob.mx/nota_detalle. php?codigo $=5361364$ \&echa $=24 / 09 / 2014$

29 Barquera S, Sánchez-Bazan K, Carriedo A. The development of a national obesity and diabetes prevention and control strategy in Mexico: actors, actions and conflicts of interest. In: Mwatsama M, ed. Public health and the food and drinks industry: the governance and ethics of interaction lessons from research, policy and practice. London: UK Health Forum, 2018: 18-30.

30 Colchero M, Rivera J, S-W N. Reducción en El consumo de bebidas Con impuesto después de la implementación del impuesto en México. insT NAC Salud Pública, 2015. Available: https://www.insp. mx/epppo/blog/3666-reduccion-consumo-bebidas.html

31 Ramirez M. Cierran 30 mil "tienditas" por reforma fiscal e inseguridad. Milenio, 2015. Available: https://www.milenio.com/ negocios/cierran-30-mil-tienditas-reforma-fiscal-inseguridad

32 Romero-Tellaeche J, Caldiño-García E, Minor-Campa E. Estudio de los efectos sobre el bienestar de la política de impuestos sobre alimentos y bebidas con alto contenido calórico. Mexico City Colegio de México; 2015.

33 Chapa-Cantú J, Flores-Curiel D, Zuñiga-Valero L. La industria de las bebidas no alcohólicas en México. Nuevo leon, 2015. Available: https://impuestosaludable.org/wp-content/uploads/2013/06/Laindustria-de-las-bebidas-no-alcohólicas-en-méxico_vf_UANL.pdf

34 Aguilar A, Gutiérrez E, Seira E. Taxing calories in Mexico, 2015. Available: http://cie.itam.mx/sites/default/files/cie/15-04.pdf

35 Consejo Coordinador Empresarial. Recomendaciones de ajustes a la legislación fiscal, 2015. Available: http://www.diputados.gob. $\mathrm{mx} /$ comhaciendaLXIII/Presentaciones/1_CCE/CCE_Presentacion. pdf

36 Contribuyente E. Las refresqueras empujaron La reducción del IEPS denuncia ONG, 2015. Available: https://www.elcontribuyente. $\mathrm{mx} / 2015 / 10 /$ las-refresqueras-empujaron-la-reduccion-del-iepsdenuncia-ong/

37 Maerker D. No hay interés de beneficiar a refresqueros: dip PRI. Con Denise Maerker, 2015. Available: https://www.radioformula. com.mx/audio-y-video/atando-cabos/20151021/no-hay-interes-debeneficiar-a-refresqueros-dip-pri-con-denise-maerker/

38 ILSI México. ILSI México: International Life Sciences Institute. Available: http://ilsi-mexico.org/ [Accessed 05/2019].

39 Rippe Lifestyle Institute. Partners \& programs, 2020. Available: http://rippehealth.com/rippelifestyle/partnersprograms.htm

40 John PC, Hill J, University of Colorado. Slight change in plans for Mexico symposium: from Dr. James Rippe. 2015 may 14. USRTK 
food ind. collect. US right to know, 2020. Available: https://www. industrydocuments.ucsf.edu/docs/qzyk0228

41 EFE. Obesidad ES un problema de calorías, no de consumo de azúcar, según expertos, 2015. Available: https://www.efe.com/ efe/america/mexico/obesidad-es-un-problema-de-calorias-noconsumo-azucar-segun-expertos/50000545-2702788

42 Federación Mexicana de Diabetes. Expertos hablan sobre relación entre consumo de azúcares $Y$ aumento de obesidad, 2015. Available: http://fmdiabetes.org/expertos-hablan-sobre-relacionentre-consumo-de-azucares-y-aumento-de-obesidad/

43 Rippe J. Sweeteners and health. Sweeteners and health; September, 2015, Mexico City, 2015.

44 White J, Sievenpiper J, Rippe J. Sweeteners and health: a review of the scientific literature.. Mexico City ILSI Mexico; 2015.

45 Redacción R. Denuncian 'ciencia chatarra'. Reforma., 2015. Available: https://www.reforma.com/aplicaciones/articulo/default. aspx?id $=632456 \& v=3 \&$ referer $=-7 \mathrm{~d} 616165662 f 3 a 3 a 6262623 b 727 \mathrm{a}$ 7a7279703b767a78-

46 Alianza por la Salud Alimentaria. Corporaciones de alimentos y bebidas traen "ciencia chatarra" a México para negar daños a salud y combatir el impuesto - Alianza por la Salud Alimentaria, 2015. Available: https://alianzasalud.org.mx/2015/09/corporaciones-dealimentos-y-bebidas-traen-ciencia-chatarra-a-mexico-para-negardanos-a-salud-y-combatir-el-impuesto/

47 ILSI. International Life Sciences Institute Suspends ILSI Mexico's Charter, 2015. Available: https://ilsi.org/wp-content/uploads/2019/ 06/ILSI-Mexico-Suspension.pdf

48 Peters JC. University of Colorado Anschutz Health and Wellness Center. [Email from John C Peters Regarding the Update]. 2015 Novemb. 09. USRTK Food Ind. Collect. US Right to Know, 2020. Available: https://www.industrydocuments.ucsf.edu/food/docs/\#id= hmlk0228

49 Comisión de Hacienda y Crédito Público. Declaratoria de publicidad de dictámenes. Mexico, 2015. Available: http://gaceta.diputados. gob.mx/PDF/63/2015/oct/20151019-III-1.pdf

50 Senado de México, Sesión ordinaria de la H. Cámara de senadores celebrada El miércoles 28 de octubre del 2015, 2015. Available: https://www.senado.gob.mx/64/version_estenografica/2015_10_28/ 1660

51 Eventos y Noticias. Conferencia "Obesity: causes and public policy responses", 2016. Available: https://eventos.itam.mx/es/3/ eventos/2016/03/09/conferencia-obesity-causes-and-public-policyresponses

52 Impuestos Calóricos, 2016. Available: http://impuestoscaloricos. $\mathrm{com} /$ [Accessed 07/2020]

53 Goltzman M, Chantereau E. FW: inform: France Tax threats defeated. 2015 December 21. DC leaks Coca Cola Emails. DC leaks, 2020. Available: https://www.industrydocuments.ucsf.edu/food/docs/\#id= rtcl0226

54 Goltzman M. Fwd: JQ interview El Tiempo Colombia 013016. 2016 January 31. DC leaks Coca Cola Emails. DC leaks, 2020. Available: https://www.industrydocuments.ucsf.edu/food/docs/\#id=mycl0226

55 Goltzman M. Waichungo W, Sancroft. Please Take Note: SRA Top Issues - Policy Briefs. 2016 January; DC Leaks Coca Cola Emails. DC Leaks, 2020. Available: https://www.industrydocuments.ucsf. edu/food/docs/\#id=mycl0226

56 Goltzman M, Banks H. Inform: Israel Tax threat. 2016 April 18. DC leaks Coca Cola Emails. DC leaks, 2020. Available: https://www. industrydocuments.ucsf.edu/food/docs/\#id=tmcl0226

57 Goltzman M. FW: INFORM: global government relations dashboard March 2016. 2016 April 04. DC Leaks Coca Cola Emails. DC Leaks, 2020. Available: https://www.industrydocuments.ucsf.edu/docs/ grcl0226

58 Coca Cola Europe. Radar screen of EU public policies. monthly issue update: February and March 2016, 2020. Available: https:// www.documentcloud.org/documents/3409808-EU-Radar-ScreenIssue-Update-2016-02-03.html

59 Goltzman M. FW: INFORM: Mexico excise tax materials \& resources. 2015 July 15. DC Leaks Coca Cola Emails. DC Leaks, 2019. Available: https://www.industrydocuments.ucsf.edu/food/docs/\#id= pfdl0226

60 World Health Organization. Report of the Commission on ending childhood obesity. Geneva, Switzerland, 2016. Available: http://apps. who.int/iris/bitstream/10665/204176/1/9789241510066_eng.pdf? ua $=1$

61 Lemming J, Goltzman M. Inform: new York times article on soda taxes. 2016 March 14. DC leaks Coca Cola Emails. DC leaks. DC leaks Coca Cola Emails. DC leaks, 2016. Available: https://www. industrydocuments.ucsf.edu/docs/lrcl0226

62 Goltzman M, Tressler K. Inform: walls street Journal study in beverage Tax impact in Mexico. DC leaks. Coca Cola Emails, 2016. Available: https://www.industrydocuments.ucsf.edu/docs/gkcl0226

63 International Council of Beverages Association. International council of beverages associations' response to health affairs journal article on the Mexico Sugar-Sweetened Beverage Tax. Press release, 2017. Available: http://www.icba-net.org/news-events/news/details/ 19/

64 International Council of Beverages Association. A dozen reasons why soft drink taxes fall flat (fact sheet), 2016. Available: https:// www.icba-net.org/files/resources/final-icba_12-reasons-why_ english.pdf

65 Sassi F, Belloni A, Mirelman AJ, et al. Equity impacts of price policies to promote healthy behaviours. Lancet 2018;391:2059-70.

66 Goltzman M, Vermeulen W. FW: inform: World health assembly may 23-28. DC leaks Coca Cola Emails. DC leaks, 2016. Available: https://www.industrydocuments.ucsf.edu/docs/kqcl0226

67 World Health Organization. Time to deliver: report of the who independent high-level Commission on noncommunicable diseases. Geneva, Switzerland: World Health Organization, 2018.

68 International Council of Beverages Association. Re: comments on the draft first report of the who independent high-level Commission on non-communicable diseases, 2018. Available: https://www.who. int/ncds/governance/high-level-commission/International-Councilof-Beverages-Associations.pdf?ua $=1$

69 Keaten J, Cheng MUS. Blocks un health panel from backing taxes on sugar drinks. PBS, 2018. Available: https://www.pbs.org/ newshour/health/un-health-panel-backs-away-from-taxing-sugarydrinks

70 Guerrero-López CM, Molina M, Colchero MA. Employment changes associated with the introduction of taxes on sugar-sweetened beverages and nonessential energy-dense food in Mexico. Prev Med 2017:105S:S43-9.

71 Colchero MA, Guerrero-López CM, Molina M, et al. Beverages sales in Mexico before and after implementation of a sugar sweetened beverage Tax. PLoS One 2016;11:4-11.

72 Popkin BM. Mexican cohort study predates but predicts the type of body composition changes expected from the Mexican sugarsweetened beverage Tax. Am J Public Health 2017;107:1702-3.

73 Basto-Abreu A, Barrientos-Gutiérrez T, Vidaña-Pérez D, et al. Cost-Effectiveness of the sugar-sweetened beverage excise Tax in Mexico. Health Aff 2019;38:1824-31.

74 Barrientos-Gutierrez T, Zepeda-Tello R, Rodrigues ER, et al. Expected population weight and diabetes impact of the 1-pesoper-litre Tax to sugar sweetened beverages in Mexico. PLoS One 2017:12:1-15.

75 Sánchez-Romero LM, Penko J, Coxson PG, et al. Projected impact of Mexico's sugar-sweetened beverage Tax policy on diabetes and cardiovascular disease: a modeling study. PLoS Med 2016;13:e1002158.

76 Crosbie E, Sosa P, Glantz SA. Costa Rica's implementation of the framework convention on tobacco control: overcoming decades of industry dominance. Salud Publica Mex 2016;58:62-70.

77 White M, Barquera S. Mexico adopts food warning labels, why now? Health Syst Reform 2020;6:e1752063.

78 Crosbie E, Thomson G, Freeman B, et al. Advancing progressive health policy to reduce NCDS amidst international commercial opposition: tobacco standardised packaging in Australia. Glob Public Health 2018;13:1753-66.

79 Bhatta DN, Crosbie E, Bialous SA, et al. Defending comprehensive tobacco control policy implementation in Nepal from tobacco industry interference (2011-2018). Nicotine Tob Res 2020;22:2203-12.

80 Crosbie E, Sosa P, Glantz SA. The importance of continued engagement during the implementation phase of tobacco control policies in a middle-income country: the case of Costa Rica. Tob Control 2017;26:60-8.

81 Mialon M, Gaitan Charry DA, Cediel G, et al. 'I had never seen so many lobbyists': food industry political practices during the development of a new nutrition front-of-pack labelling system in Colombia. Public Health Nutr 2021;24:2737-45.

82 World Health Organization. Fiscal policies for diet and prevention of noncommunicable diseases. Technical meeting report. Geneva, Switzerland: World Health Organization, 2015. 